\title{
Perception towards Online Classes during COVID-19 among MBBS and BDS Students in a Medical College of Nepal: A Descriptive Cross- sectional Study
}

\author{
Nitasha Sharma, ${ }^{1}$ Chet Kant Bhusal, ${ }^{2}$ Sandip Subedi, ${ }^{3}$ Rajeshwar Reddy Kasarla ${ }^{4}$ \\ 'Department of Anatomy, Universal College of Medical Sciences and Teaching Hospital, Bhairahawa, Rupandehi, \\ Nepal, ${ }^{2}$ Department of Community Medicine, Universal College of Medical Sciences and Teaching Hospital, \\ Bhairahawa, Rupandehi, Nepal, ${ }^{3}$ Department of Psychiatry, Universal College of Medical Sciences and Teaching \\ Hospital, Bhairahawa, Rupandehi, Nepal, ${ }^{4}$ Department of Microbiology, Universal College of Medical Sciences and \\ Teaching Hospital, Bhairahawa, Rupandehi, Nepal.
}

\section{ABSTRACT}

Introduction: Sudden outbreak of COVID-19 pandemic has affected the educational system worldwide, forced the medical colleges to close due to lock down, and disrupted the classroom face-to-face teaching process. As a result, medical colleges shifted to an online mode of teaching. The aim of this study is to find out the perception towards online classes during COVID-19 lockdown period among MBBS and BDS students at medical college of Nepal.

Methods: This was a descriptive cross-sectional study carried out at Universal College of Medical Sciences and Teaching Hospital among first and second year Bachelor in Medicine, Bachelor of Surgery and Bachelor in dental surgery students from 1st June 2020 to 30th August 2020. Ethical approval was taken from Institutional Review Committee of Universal College of Medical Sciences and Teaching Hospital (IRC UCMS, Ref: UCMS/IRC/025/20). Convenient sampling method was used. Semi-structured questionnaire was used. Statistical Package for Social Sciences 22 was used for analysis and frequency and percentage was calculated.

Results: One hundred fifty six (73.93\%) students were enjoying online learning only to some extent, 135 (63.98\%) felt online class not equally effective as face-to-face teaching. The students had disturbance during online classes as internet disturbance $168(79.60 \%)$, and electricity problem 47 (22.3\%). Similarly, many students $155(73.50 \%)$ felt external disturbance, headache $26(12.3 \%)$, and eye strain $26(12.3 \%)$.

Conclusions: Most of the students suffered from disturbances during online classes probably because of internet and electricity problem. When compulsory to conduct online classes, students felt that not more than three online classes per day should be conducted to avoid eye strain and headache.

Keywords: face-to-face teaching; medical students; online learning.

\section{INTRODUCTION}

The global pandemic COVID-19 has made an impact on each and every field. Medical education is no exception to it, with lockdown and social distancing measures face to face classes are abandoned. ${ }^{1}$ This forced educational institutions to shift to an online mode of teaching-learning, which is an imperfect yet quick solution to the crises. ${ }^{2}$ As per guidelines of Ministry of health and education, Universal College of Medical Sciences (UCMS) also started online classes. ${ }^{3}$
Online learning is a relatively new phenomenon, currently both the Teachers and students are struggling with the idea of its implementation and adaptation respectively. ${ }^{4}$ In a developing country like Nepal, several technological, education/literacy background

Correspondence: Dr. Nitasha Sharma, Department of Anatomy, Universal College of Medical Science and Teaching Hospital, Bhairahawa, Rupandehi, Nepal. Email: sharmanitasha8868@gmail. com, Phone:+977-9849288600. 
and socioeconomic challenges exist, which might act as a hindrance to the online learning process. ${ }^{5,6}$

The aim of this study is to the perception towards online classes and learning during COVID-19 lockdown period among MBBS and BDS students at a medical college of Nepal.

\section{METHODS}

A descriptive cross-sectional study was conducted among $1^{\text {st }}$ and $2^{\text {nd }}$ year Bachelor of Medicine and Bachelor of Surgery (MBBS) and Bachelor of Dental Surgery (BDS) at Universal College of Medical Sciences, Bhairahawa, Nepal from $1^{\text {st }}$ June 2020 to $30^{\text {th }}$ August 2020.

Ethical approval was taken from Institutional Review Board of Universal college of Medical Sciences and Teaching Hospital, Bhairahawa, Rupandehi, Nepal (IRC UCMS, Ref: UCMS/IRC/025/20). The objectives of the study were briefed to respondents. Written informed consent was taken from the students and additional verbal consent was taken from the students' parents through telephone for those students who were below 18 years of age. The data was used only for this study purpose and confidentiality of the data has been maintained.

All the medical and dental students studying in $1^{\text {st }}$ and $2^{\text {nd }}$ year at UCMS Bhairahawa, Nepal and wiliness to participate in the study were included in the study. Similarly those who were not wiliness to participate and those who did not fill questionnaire completely until the study period were excluded from the study. Convenient sampling method was used. A total of 211 questionnaires were completely filled and included in the study.

The minimum sample size was estimated using the following formula:

$\mathrm{n}=\mathrm{Z}^{2} \times \mathrm{p} \times \mathrm{q} / \mathrm{e}^{2}$

$=(1.96)^{2} \times 0.5 \times(1-0.5) /(0.07)^{2}$

$=196$

Where,

$Z=1.96$ for confidence interval at $95 \%$

$\mathrm{p}=$ prevalence, $50 \%$

$q=1-p$

$\mathrm{e}=$ margin of error, $7 \%$

Collected data were cross checked every day to ensure all the questions have been filled. All the collected data were entered into Microsoft excel and exported to SPSS version 22 for analysis. Simple frequency tables, cross tables and mean tables have been used to analyze data related to the study. Characteristics of the sample were categorized using mean and standard deviation.

\section{RESULTS}

The mean age was $20.13 \pm 1.19$ years for the respondents. The age of the respondents was categorized on the basis of mean age 20. The finding revealed that nearly two-third $132(62.56 \%)$ of the students were less than equal to 20 years. Twothird of respondents $140(66.35 \%)$ resides in rural municipalities. Caste/Ethnicity was categorized as per Nepal caste and ethnic groups with regional divisions and social groups (Table 1).

\begin{tabular}{|l|l|}
\hline $\begin{array}{l}\text { Table 1. Distribution of socio-demographic } \\
\text { characteristics of study. }\end{array}$ \\
\hline General characteristics & $\mathbf{n ~ ( \% )}$ \\
\hline Age & \\
\hline$\leq 20$ years & $132(62.56)$ \\
\hline$>20$ years & $79(37.44)$ \\
\hline Mean age \pm SD & $20.13 \pm 1.19$ \\
\hline Gender & $104(49.26)$ \\
\hline Male & $107(50.71)$ \\
\hline Female & \\
\hline Residence & $71(33.65)$ \\
\hline $\begin{array}{l}\text { Urban (Sub-metropolitan } \\
\text { city and Municipalities) }\end{array}$ & $140(66.35)$ \\
\hline Rural (Rural Municipalities) & \\
\hline
\end{tabular}

Regarding online classes nearly one-fourth of the respondents were not enjoying the class as per regular lecture class. Nearly two third 135 (63.98\%) of the respondents felt online classes was not equally competent as regular lectures. A large number 178 $(84.36 \%)$ of students found a great variation of online teaching from teacher to teacher (Table 2).

Table 2. Students experience during online classes.

\begin{tabular}{|l|l|}
\hline General characteristics & $\mathbf{n}(\%)$ \\
\hline Enjoying online classes & \\
\hline Not Enjoying & $50(23.70)$ \\
\hline Enjoying in some extent & $156(73.93)$ \\
\hline Enjoying fully & $5(2.37)$ \\
\hline Students' opinion about online class & \\
\hline Equally competent as regular class & $32(15.17)$ \\
\hline Not equally competent & $135(63.98)$ \\
\hline Can't say & $44(20.85)$ \\
\hline $\begin{array}{l}\text { Variation of Online teaching from } \\
\text { teacher to teacher }\end{array}$ & \\
\hline Yes & $178(84.36)$ \\
\hline No & $12(5.69)$ \\
\hline
\end{tabular}


Sharma et al. Perception towards Online Classes during COVID-19 among MBBS and BDS Students in a Medical..

Can't Say

$21(9.95)$

Most 208 (98.58\%) of the medical and dental students had taken online class for the $1^{\text {st }}$ time. More than half $113(53.55 \%)$ of the respondents used mobiles. Onethird $71(33.65 \%)$ of the students used mobile data to take the classes. Universal College of Medical Sciences and Teaching Hospital online classes were scheduled as 4-5 hours for $1^{\text {st }}$ year MBBS and BDS whereas 2-3 hours for MBBS and BDS $2^{\text {nd }}$ year. Based on average timing of the college, timing was categorized as less than equal to 4 hours and greater than 4 hours. The findings revealed that nearly two-third of the respondents had taken less than and equal to 4 hours online classes (Table 3).

\begin{tabular}{|l|c|}
\hline Table 3. Status of online classes. \\
\hline General characteristics & $\mathbf{n}(\%)$ \\
\hline Prior online classes taken & $208(98.58)$ \\
\hline No & $3(1.42)$ \\
\hline Yes & \\
\hline Gadgets used for online Class & $92(43.60)$ \\
\hline Laptop & $113(53.55)$ \\
\hline Mobile & $4(1.90)$ \\
\hline Tablet/l-pad & $2(0.95)$ \\
\hline Desktop & \\
\hline Internet Service used & $140(66.35)$ \\
\hline Wifi & $71(33.65)$ \\
\hline Mobile data & \\
\hline $\begin{array}{l}\text { Hours of online class taken } \\
\text { per day }\end{array}$ & $134(63.51)$ \\
\hline$\leq 4$ hours & $77(36.49)$ \\
\hline$>4$ hours & $4.05 \pm 1.15$ \\
\hline Mean hour $\pm S D$ & \\
\hline
\end{tabular}

Nearly four-fifth 168 (79.62\%) of the respondents faced internet disturbance during online classes. Similarly more than half $112(53.08 \%)$ of the respondents faced mobile network problem, whereas little 26 (12.32\%) had headache and eye strain due to online classes. Nearly half $112(53.08 \%)$ of the students felt economic burden during online class (Table 4).

\begin{tabular}{|l|}
\hline $\begin{array}{l}\text { Table 4. Obstacles and constraints during online } \\
\text { classes. }\end{array}$ \\
\hline General characteristics \\
\hline $\begin{array}{l}\text { Difficulties faced during } \\
\text { online class }\end{array}$ \\
\hline $\begin{array}{l}\text { Network problem } \\
\text { (telecom tower) }\end{array}$ \\
\hline
\end{tabular}

\begin{tabular}{|l|c|}
\hline Electricity problem & $47(22.28)$ \\
\hline Headache & $26(12.32)$ \\
\hline Eye Strain & $26(12.32)$ \\
\hline Internet disturbance & $168(79.62)$ \\
\hline $\begin{array}{l}\text { Felt economic burden } \\
\text { due to online class }\end{array}$ & \\
\hline Yes & $112(53.08)$ \\
\hline No & $55(26.07)$ \\
\hline Can't Say & $44(20.85)$ \\
\hline
\end{tabular}

Fifty six $(41.48 \%)$ of the students recommended to reduce the number of classes in online teaching, whereas few 20 (14.82\%) provided constructive feedback for audio visual aids. Majority 199 (94.31\%) of the respondents suggested to reduce the classes duration (Table 5).

Table 5. Students' recommendation for making online classes effective.

\begin{tabular}{|l|c|}
\hline General characteristics & $\mathbf{n ~ ( \% )}$ \\
\hline $\begin{array}{l}\text { Recommendation for competent } \\
\text { class ( } \mathrm{n}=135)\end{array}$ & $56(41.48)$ \\
\hline Reduction in number of classes & $17(12.59)$ \\
\hline Reduction in time for class & $42(31.11)$ \\
\hline Focus in two way interaction & $20(14.82)$ \\
\hline Provide audio-visual materials & \\
\hline $\begin{array}{l}\text { Recommended technique for } \\
\text { making class effective (n= 86) }\end{array}$ & $52(60.47)$ \\
\hline Focus on it advancement & $34(39.53)$ \\
\hline $\begin{array}{l}\text { Andragogy teaching style should } \\
\text { be used }\end{array}$ & 12 (5.69) \\
\hline $\begin{array}{l}\text { Students' recommendation for } \\
\text { time duration }\end{array}$ & $2.80 \pm 0.56$ \\
\hline$\leq 3$ hours per day & \\
\hline$>3$ hours per days & \\
\hline Mean recommended time $\pm S D$ & $(94.31)$ \\
\hline
\end{tabular}

\section{DISCUSSION}

This study assessed the perceptions of medical students towards E-learning. In our study, majority of students enjoying E-learning only to some extent $(73.9 \%)$, fully enjoying E-learning were just five $(2.4 \%)$, and not enjoying $50(23.7 \%)$. This study is consistent with the finding of another conducted in Oman and UAE, where some students suggested that they would prefer the traditional method too as they can get bored in a virtual environment as well as no ease with use of technology. ${ }^{7}$

Our study indicates that out of 211 students, $53.6 \%$ used mobile phones, $43.6 \%$ used laptops for online classes this is similar to 
Briz-Ponce et al study, which looked into in to mobile usage for learning among medical students of Coimbra University, and a strong attitude towards mobile use for learning (57\%) and willingness to recommend it $(40.5 \%)$ was noted.

As regards the perception of students towards online class in comparison to regular class room teaching, majority of students felt online class is not equally effective $64 \%$, and $15.1 \%$ students felt equally effective, and $33.1 \%$ could not say. A total of $86(40.8 \%)$ students felt that regular class room teaching can't be substituted by online class, while $26.1 \%$ felt can be substituted and $33.1 \%$ students couldn't say. Majority of the students preferred traditional face to face class room teaching over online classes. This finding is quite different from a study of Solimann et al which was conducted at the College of Medicine at King Saud University (Saudi Arabia) had noted that the general perceptions of the students $63.5 \%$ were positive that an e-learning enabled training would enhance their learning process. ${ }^{9}$

In our study, majority of students had disturbance during online classes as Internet disturbance $79.6 \%$, and electricity problem $22.3 \%$. Similarly, many students $73.5 \%$ felt external disturbance during online classes. This finding is in consistent with the study by Subedi S, where more than half of the students $63.2 \%$ got disturbed for their online class because of electricity problem, and $63.6 \%$ because of internet problem. ${ }^{10}$

An alarming response that we received from this study was student's response to headache and eye strain during online classes which was $25 \%$ directing towards lockdown myopia. ${ }^{11}$

The sample of our study was taken only from one college, so the findings cannot be generalized to other medical colleges. The reliability of our data is entirely based upon the correct reporting of the participants. So, call bias might occur. Furthermore, an in-depth qualitative study is necessary.

\section{CONCLUSIONS}

Most of students enjoyed the online classes to some extent where as understanding the subject content was moderate. Most of the respondents suffered from disturbances during online classes probably due to internet and electricity problem. When it is compulsory to conduct online classes, students felt that not more than three online classes per day should be conducted to avoid eye strain and headache.

\section{Conflict of Interest: None.}

\section{REFERENCES}

1. UNESCO. COVID-19 Educational Disruption and Response [Internet]. UNESCO. 2021 Mar 28. [cited march 29]. Available from: http://www.iiep.unesco.org/en/covid-19-educational-disruption-and-response-13363. [Full Text]

2. Ferrel MN, Ryan JJ. The impact of COVID-19 on medical education. Cureus. 2020 Mar 31;12(3):e7492. [Full Text | DOI]

3. Ministry of Education,Science and Technology, Government of Nepal. Notice [Internet]. Kathmandu, Nepal: Ministry of Education,Science and Technology, Government of Nepal; 2020 Mar 3. [cited 2021 Jan 12]. Available from: http://www. moe.gov.np/article/1299/notice-2.html. [Full Text]

4. Affouneh S, Salha S, Khlaif ZN. Designing quality E-Learning environments for emergency remote teaching in Coronavirus crisis. Interdiscip J Virtual Learn Med Sci. 2020;11(2):1-3. [Full Text | DOI]

5. Basilaia G, Dgebuadze M, Kantaria M, Chokhonelidze G. Replacing the classic learning form at universities as an immediate response to the COVID-19 virus infection in Georgia. International Journal for Research in Applied Science and Engineering Technology (IJRASET). 2020 Mar;8(3):101-8. [Full Text | DOI]

6. Reddy KR. Challenges in conducting MBBS program in a Nepalese Medical College. Journal of Gandaki Medical College-Nepal. 2017;10(1):49-56. [Full Text | DOI]
7. Surkhali B, Garbuja C. Virtual learning during COVID-19 pandemic: pros and cons. Journal of Lumbini Medical College. 2020;8(1):154-5. [Full Text | DOI]

8. Briz-Ponce L, Pereira A, Carvalho L, Juanes-Mendez JA, Garcia-Penalvo FJ. Learning with mobile technologiesStudents' behavior. Computers in Human Behavior. 2017 Jul;72:612-20. [ Full Text | DOI]

9. Soliman MM, Sattar K, Alnassar S, Alsaif F, Alswat K, Alghonaim $\mathrm{M}$, et al. Medical students' perception of the learning environment at King Saud University Medical college, saudi Arabia, using DREEM inventory. Adv Med Edu Prac. 2017 Mar;8:221-7. [PubMed | Full Text | DOI]

10. Subedi S, Nayaju S, Subedi S, Shah SK, Shah JM. Impact of E-learning during COVID-19 Pandemic among Nursing Students and Teachers of Nepal. International Journal of Science \& Healthcare Research. 2020;5(3):68-76. [Full Text]

11. Sumitha M, Sanjay S, Kemmanu V, Bhanumathi MR, Shetty R. Will COVID-19 pandemic-associated lockdown increase myopia in Indian children? Indian J Ophthalmol. 2020;68(7):1496. [PubMed | Full Text | DOI

This work is licensed under a Creative Commons Attribution 4.0 International License. The images or other third party material in this article are included in the article's Creative Commons license, unless indicated otherwise in the credit line; if the material is not included under the Creative Commons license, users will need to obtain permission from the license holder to reproduce the material. To view a copy of this license, visit http://creativecommons.org/licenses/by/4.0/ 